\title{
The Influence of Non-State-Owned Shareholders on Auditor Selection in Mixed Reform of State-Owned Enterprises
}

\author{
CHEN Ping \\ Beijing Jiaotong University, Haidian District, Beijing, China \\ 1485922145@qq.com
}

\begin{abstract}
Keywords: Mixed Reform of State-owned Enterprises, Auditor selection, Ownership structure.
\end{abstract}
\begin{abstract}
The mixed ownership reform of state-owned enterprises is an important tendency of current and future reform of state-owned enterprises in China. Improving the corporate governance level of state-owned enterprises is one of important causes of the reformation. Considering the important role of auditing in corporate governance, this paper tests the influence of non-state-owned major shareholders on auditor selection of state-owned enterprises by using China's A-share state-owned listed companies from 2008 to 2017 as research samples. The study found that the participation of non-state-owned shareholders in the governance of state-owned enterprises increased the demand for high-quality audit. Further research shows that different administrative levels and industrial competition degree have no significant influence on non-state-owned shareholders' participation in state-owned enterprise's corporate governance.
\end{abstract}

\section{Introduction}

China's special institutional arrangements have formed a situation in which China's diversified property rights coexist. The state-owned enterprises account for a large proportion of listed companies in China. Mixed ownership reform of state-owned enterprises is an important direction of current and future reform of state-owned enterprises, it's one of the key content of the economic system reform in China and has become an important research topic in the field of corporate governance (Yang xingquan and Yin xingqiang, 2018).

The impetus of state-owned enterprise reform is to improve the operating efficiency of state-owned enterprises by introducing non-state-owned capital, and its essence is to improve the corporate governance mechanism (Hao yang and Gong liutang, 2017). The entry of non-state-owned capital can alleviate the long-standing problems of "unclear property rights", "absence of owners", excessive government control and intervention, and "insider control" in state-owned enterprises (Zhang weiying, 1996; Liu guoyun et al., 2016), reduce agency costs and improve corporate governance (Yang xingquan, 2018; Ma yong et al., 2019). Non-state-owned shareholders can directly improve the level of corporate governance by reducing agent cost (Liu guoyun et al., 2016; Zeng shiyun et al., 2017), and it can also indirectly promote the improvement of corporate governance by influencing auditor selection and changing the external supervision environment (Ma yong et al., 2019).

Ownership structure is one of the key factors in determining the quality of corporate governance. Auditing is an important part in external supervision, the audit quality has important reference value to measure the level of corporate governance. Does the mixed reform of state-owned enterprises improve the level of corporate governance and reflect it through the improvement of external audit quality and audit fees? In this regard, the existing literature has not been fully studied.

In order to explore the above issues, this paper takes listed companies in China's A stock market as research samples to test the influence of non-state-owned major shareholders on the selection of state-owned enterprises' auditors. The study found that non-state-owned major shareholders can participate in the governance of state-owned enterprises by exercising voting rights and appointing senior executives, moreover, the participation can improve the demand for high-quality audit.

The possible research innovation and significance of this paper are mainly reflected in the following two aspects. Firstly, based on the external supervision function of audit, this paper discusses the effect of non-state-owned shareholders on the external governance mechanism of state-owned 
enterprises, so enriches the existing literature on mixed ownership reform from the perspective of auditor selection. Secondly, there is no unified consensus on auditor selection under different property rights and equity nature. This paper uses the dynamic perspective of mixed ownership reform of stateowned enterprises to examines the increasing demand for high-quality audit caused by the introduction of non-state-owned capital, and expands the relevant research on auditor selection.

\section{Literature review}

\subsection{Factors influencing the auditor selection}

Studies show that audit quality provided by accounting firms varies (Watts and Zimmerman, 1981), and the scale of the firms can be used as a proxy variable of audit quality (DeAngelo, 1981). Tested by practice and academic research, choosing "Big N" indicates the need for high-quality auditing.

Most of the literatures have carried out empirical tests on auditor selection based on agency theory. According to the agency theory of audit demand, audit has the function of restraining agent's opportunism behavior and reducing agent cost. Jensen and Meckling (1976) believe that auditors with non-zero independence can reduce agency costs by supervising the execution of corporate contracts. High-quality audit has the function of corporate governance (Fan and Wong,2005), hiring highquality auditors is an important part of modern corporate governance (Watts and Zimmerman, 1983). In the perspective of corporate governance, supervision demand is the basic driving force of audit quality demand (Chen hanwen, 2012; Joseph and Wong, 2001). Sun zheng and Yu xuhui (2007) showed that the more serious the agency conflict, the higher the demand for the five major international accounting firms. However, there is also a view that when the agency conflict is serious enough and high quality of other governance mechanisms is absent, small-scale accounting firms will prevail (Wilson,1988).

\subsection{Equity characteristics and auditor selection}

As a major determinant of corporate governance level (Shleifer and Vishny,1997), equity characteristics of a company have an important impact on auditor selection (Ashbaugh and Warfield,2003; Liu minghui, Hu bo, 2006). Though there are lots of empirical research about the relationship between corporate governance, ownership structure and auditor selection, no consensus has been reached. The overall conclusion tends to be that when the agency conflict is more serious and the proportion of state-owned equity is higher, the lower the demand for high-quality auditors. However, the existing literature mainly discusses the ownership structure from the aspects of ownership nature and shareholding ratio. Few literatures make in-depth analysis on the relationship between the ownership structure and auditor selection caused by the differentiation of high-level governance structure. Besides, according to the existing literature, the institutional environment will affect the behavior of stakeholders in the securities market and the demand for external audit (Choi and Wong, 2005; Zhang Ming et al., 2012). China has basically completed the reform of non-tradable shares since 2007, and the reform of mixed ownership of state-owned enterprises has been continuously promoted since 2013. However, researches on the relationship between ownership structure and auditor selection in this background is still insufficient.

\section{Theoretical analysis and research hypothesis}

Numerous studies have shown that the governance efficiency of state-owned shareholders is lower and there is no motivation for high-quality audit (Sun zheng et al., 2004; Han hongling, Chen hanwen, 2008). One of the purposes of mixed-ownership reform is improving the quality of corporate governance by forming a diversified and balanced ownership structure (Hao yunhong and Wang qian, 2016; Zeng shiyun et al., 2017). The introduction of non-state-owned shareholders makes the subject of property rights of state-owned enterprises more clear(Ma lianfu et al., 2015), and weakens the problem of insider control (Huang suojian, 2014). From the perspective of auditing demand, highquality audit can effectively reduce agency cost, send positive signals to the external market and 
reduce financing cost (Fan and Wang, 2005). Driven by the profit-seeking nature of non-state-owned shareholders, they have higher demand for high-quality audit. Therefore, hypothesis H1 is put forward: the introduction of non-state-owned shareholders in state-owned enterprises can enhance the demand for high-quality audit and improve the level of corporate governance.

Due to the control intensity on enterprises given by different levels of government varies, the actual administrative level of the controller may affect the exercise of governance power of non-state-owned major shareholders (Liu yunguo et al., 2016). First of all, the special status and mission of central enterprises make them subject to strict supervision by relevant departments of the state. Even if external investors are introduced, they are usually financial investors and rarely take participate in major decision making. Second, the central enterprises have strong strength and are highly valued by the government. They have abundant internal and external resources to improve the level of corporate governance so the quality of corporate governance is higher. Therefore, compared with central enterprises, local state-owned enterprises have more space and potential to improve the level of corporate governance. Accordingly, hypothesis $\mathrm{H} 2$ is proposed: compared with central enterprises, the shareholding of non-state-owned major shareholders has a more obvious effect on the improvement of audit quality in local enterprises.

State-owned enterprises can be divided into competitive one and the monopolistic one according to the different degree of competition. Participating in the sharing of monopoly earnings is an important motive for non-state-owned enterprises to invest in monopolistic state-owned enterprises. Monopoly industry participants can obtain high returns without fierce competition, and thus shareholders have no impetus to improve corporate governance. By contrast, competitive state-owned enterprises face fierce market competition environment, they must improve the efficiency of corporate governance and management on various aspects to enhance their competitiveness, so as to improve the efficiency of the enterprise and achieve the goal of maximizing the wealth for shareholders. Therefore, hypothesis H3 is put forward: compared with monopolistic state-owned enterprises, non-state-owned shareholders' demand for high-quality audit is more obvious in competitive state-owned enterprises.

\section{Theoretical analysis and research hypothesis}

\subsection{Sample selection and data sources}

Since the reform of non-tradable shares in China was only completed in 2007, referring to the existing literature (Cai guilong et al., 2018), the paper selects state-owned enterprises listed in A-share from 2008 to 2017 as research samples. In order to ensure the reliability and stability of the data, listed companies in the financial industry, companies that had been ST during the study and those whose property rights were changed into non-state-owned enterprises were excluded. Non-state-owned shareholders' shareholding data and personnel appointment data were collected according to annual report. Other sample data were obtained from CSMAR database.

\subsection{Empirical model and variable definition}

Based on the previous literatures' research design (Ma yong et al. 2019) and the measurement index for mixed reform degree (Cai guilong et al. 2018), this paper constructs the following model to test the above hypotheses:

$$
\text { Auditor }=\alpha+\beta_{1} \text { NonSOE }+\alpha_{2} \text { Controls }+\varepsilon
$$

Auditor is a dummy variable that indicates whether the Auditor is "Big 4" or not. NonSOE is a series of primary test variables that measure the degree which non-state-owned shareholders participate in the governance of state-owned enterprises. Referring to relevant literatures, this paper measures the participation from two levels: the shareholding ratio and personnel appointment. OMD indicats the degree of equity mixing between non-state-owned and state-owned shares. OMDC represents the depth of non-state-owned shareholders' equity. DEL_PRO is the proportion of directors appointed by non-state shareholders, DEL is the number of directors appointed by non-state 
shareholders. OMD and DEL_PRO are used for master test, OMDC and DEL are used for robustness test.

Table 1. Name and meaning of main variables.

\begin{tabular}{|c|c|c|}
\hline Variable name & Abbreviation & Variable definition and description \\
\hline $\begin{array}{c}\text { Auditor } \\
\text { selection }\end{array}$ & Auditor & Firm for international Big 4 takes 1 , otherwise 0 \\
\hline \multirow{4}{*}{$\begin{array}{l}\text { Non-state } \\
\text { shareholder } \\
\text { participation }\end{array}$} & OMD & $\begin{array}{l}\text { Equity mix degree: the share percentage of non-state-owned } \\
\text { shareholders in the top } 10 \text { shareholders }\end{array}$ \\
\hline & OMDC & $\begin{array}{l}\text { Equity depth: the total shareholding ratio of the top } 10 \text { non- } \\
\text { state-owned shareholders }\end{array}$ \\
\hline & DEL & Director numbers appointed by non-state shareholders \\
\hline & DEL_PRO & The proportion of directors appointed by non-state shareholders \\
\hline \multirow{11}{*}{ Controls } & LnAsset & Company size: logarithm of ending total assets \\
\hline & arat & Accounts receivable and inventory as a proportion of total assets \\
\hline & invat & Inventory as a percentage of total assets \\
\hline & Liq & liquidity ratio \\
\hline & Lev & debt-to-assets ratio \\
\hline & Loss & If net profit is negative, it's 1 , otherwise it's 0 \\
\hline & ifmhold & Whether management holds shares \\
\hline & Roa & Return on total assets \\
\hline & Growth & Total Assets Growth Rate \\
\hline & Center & Central enterprises take 1 , otherwise 0 \\
\hline & Longd & Monopoly state-owned enterprises take 1 , otherwise it is 0 \\
\hline
\end{tabular}

\section{The empirical analysis}

\subsection{Descriptive statistics}

Table 2 reports the results of descriptive statistics for major variables. According to the company law of China, after the shareholding ratio reaches a certain share, the shareholders can exercise the right to vote by participating in the voting, thus affecting corporate governance and operation. Besides, shareholders of listed companies appoint senior executives as an important way to participate in corporate governance, so the corporate governance effect played by non-state-owned shareholders' participation in mixed reform may also be realized by appointing senior executives.

Table 2. Descriptive statistics of main variables.

\begin{tabular}{lcccccc}
\hline variable & $\mathrm{N}$ & mean & $\mathrm{sd}$ & $\min$ & $\mathrm{p} 50$ & $\max$ \\
auditor & 9208 & 0.0959 & 0.294 & 0 & 0 & 1 \\
\hline DEL & 9208 & 0.272 & 0.714 & 0 & 0 & 9 \\
DEL_PRO & 9208 & 0.0299 & 0.0800 & 0 & 0 & 1 \\
OMD & 9208 & 0.240 & 0.168 & 0.00410 & 0.199 & 0.817 \\
OMDC & 9208 & 0.135 & 0.106 & 0.00370 & 0.105 & 0.669 \\
longd & 9208 & 0.136 & 0.343 & 0 & 0 & 1 \\
center & 9208 & 0.334 & 0.472 & 0 & 0 & 1 \\
\hline
\end{tabular}

\subsection{The relationship of auditor selection and non-state shareholder in the mixed reform}

For the relationship between non-state-owned shareholders' participation in corporate governance and auditor selection, the first two columns of table 3 show the basic regression results. The explanatory variables measuring the degree of mixed reform from the two dimensions of non-state-owned shareholders' shareholding ratio and personnel appointment are positively correlated with the selection of Big4 at the level of 1\%. The regression results show that non-state-owned shareholders' participation in corporate governance can enhance the demand for high-quality audit, non-stateowned shareholders' shareholding and personnel appointment are both important means for non-stateowned shareholders to participate in corporate governance. Hypothesis 1 is true. 
Table 3. The participation degree of non-state-owned shareholders and auditor selection.

\begin{tabular}{|c|c|c|c|c|}
\hline & \multicolumn{2}{|c|}{ Basic regression results } & \multicolumn{2}{|c|}{ Robust regression results } \\
\hline DEL_PRO & $\begin{array}{c}2.685^{* * * *} \\
(5.68)\end{array}$ & & & \\
\hline OMD & & $\begin{array}{c}2.031 * * * \\
(6.86)\end{array}$ & & \\
\hline DEL & & & $\begin{array}{r}0.321^{* * *} \\
(6.28)\end{array}$ & \\
\hline OMDC & & & & $\begin{array}{c}3.746^{* * * *} \\
(9.12)\end{array}$ \\
\hline Controls & yes & yes & yes & yes \\
\hline Year & Control & Control & Control & Control \\
\hline Industry & Control & Control & Control & Control \\
\hline$N$ & 8101 & 8101 & 8101 & 8101 \\
\hline $\operatorname{adj} . R^{2}$ & 0.3544 & 0.3578 & 0.3555 & 0.3646 \\
\hline
\end{tabular}

\subsection{Further research: administrative level and industry competition}

The first two columns in table 4 shows the influence of non-state-owned shareholders' participation in corporate governance on auditor selection in state-owned enterprises at different administrative levels. In both local state-owned enterprises and central state-owned enterprises, the indexes representing the participation degree of non-state-owned shareholders in corporate governance are positively correlated with the selection of Big4 at the level of $1 \%$, which is inconsistent with hypothesis 2 . It shows that the different administrative levels of state-owned enterprises do not have a significant impact on the participation of non-state-owned major shareholders in the external governance of the company.

Table 4. Further research: administrative level and industry competition.

\begin{tabular}{lcc|cc}
\hline & \multicolumn{2}{c|}{ Central enterprise } & $\begin{array}{c}\text { Local state-owned } \\
\text { enterprise }\end{array}$ \\
\hline DEL_PRO & $5.910^{* * *}$ & & $2.359^{* * *}$ \\
& -5.94 & -4.3 & \\
OMD & & $\begin{array}{c}2.835^{* * *} \\
-5.4\end{array}$ & & $\begin{array}{c}2.237^{* * * *} \\
-5.79\end{array}$ \\
Controls & yes & yes & yes & yes \\
Year & Control & Control & Control & Control \\
\hline Industry & Control & Control & Control & Control \\
\hline$N$ & 2488 & 2488 & 4586 & 4586 \\
adj. $R^{2}$ & 0.4655 & 0.4621 & 0.3421 & 0.3486 \\
\hline$t$ statistics in parentheses: ${ }^{*} p<0.1,{ }^{* *} p<0.05,{ }^{* * *} p<0.01$
\end{tabular}

\begin{tabular}{cc|cc}
\hline $\begin{array}{c}\text { Monopolistic state- } \\
\text { owned enterprise }\end{array}$ & $\begin{array}{c}\text { Competitive state- } \\
\text { owned enterprise }\end{array}$ \\
\hline $6.648^{* * *}$ & & $2.035^{* * *}$ & \\
-6.27 & & -4.21 & \\
& $3.427 * * *$ & & $1.677 * * *$ \\
& -4.71 & & -4.87 \\
yes & yes & yes & yes \\
Control & Control & Control & Control \\
\hline Control & Control & Control & Control \\
\hline 1250 & 1250 & 6851 & 6851 \\
0.3835 & 0.3784 & 0.3636 & 0.3611 \\
\hline
\end{tabular}

The last two columns in table 4 shows the influence of non-state-owned shareholders' participation on auditor selection under different degrees of competition. In monopolistic and competitive stateowned enterprises, the coefficient of DEL_PRO and OMD are both significantly positive at the level of $1 \%$, though the absolute coefficient of DEL_PRO and OMD of monopolistic state-owned enterprises is higher than that of competitive state-owned enterprises, which is inconsistent with hypothesis 3 . The reason may be explained by the following: the huge excess returns in monopolistic state-owned enterprises motivates non-state-owned shareholders to seek external supervision in order to maximize their own interests and avoid being harmed by state-owned shareholders.

\subsection{Robustness test}

OMDC and DEL are used to replace OMD and DEL_PRO, the result is shown in the last two columns of table 2, both OMDC and DEL are positively correlated with high-quality auditor selection at the $1 \%$ level, supporting the main findings of this paper. In addition, this paper used the natural logarithm 
of the fee as alternative indicators of quality audit, found OMDC and OMD were positively correlated at 5\% level, while DEL_PRO and DEL had no significant correlation with audit fee.

\section{Research conclusion and enlightenment}

This paper examines the effect of non-state-owned shareholders' participation in the governance of state-owned enterprises from the perspective of auditor selection, and further distinguishes the regulatory effect of the administrative level of state-owned enterprises and the degree of industry competition on non-state-owned shareholders' participation in corporate governance. The main conclusions of this paper are as follows: firstly, non-state-owned shareholders can increase the demand for high-quality audit, which indicates that the participation of non-state-owned shareholders in corporate governance can alleviate agency costs, exert governance effect and improve the external governance level of enterprises. Secondly, different administrative levels and industrial competition degree have no significant impact on the selection about auditor. The participation of non-state-owned major shareholders in mixed reform still has a significant effect on the demand for high-quality audit, even in monopolistic state-owned enterprise and central enterprise.

Exploring the governance effect of non-state-owned shareholders may give us the following enlightenment. Firstly, the mixed reform of state-owned enterprises should actively introduce nonstate-owned investors, constantly optimize the property structure of state-owned enterprises, and improve the efficiency of property allocation of state-owned enterprises. Secondly, non-state-owned shareholders can participate in the governance of state-owned enterprises either through formal voting rights or through personnel appointment. Therefore, in the mixed reform of state-owned enterprises, the right of non-state-owned shareholders should be guaranteed in multiple dimensions and the positive governance effect of non-state-owned shareholders should be maximized.

\section{References}

[1] Ma yong, Wang man,Ma ying, et al. Do non-state-owned major shareholders influence the selection of state-owned auditor? [J]. Audit and economic research, 2019, 34(02):23-34.

[2] Liu yunguo, Zheng qiao, Cai guilong. Do non-state-owned shareholders improve the quality of internal control in state-owned enterprises? -- empirical evidence from state-owned listed companies [J]. Accounting research, 2016(11).

[3] Zeng shiyun, Cai guilong, Cheng minying. Can non-state shareholders improve the quality of accounting information? -- empirical evidence from competitive state-owned listed companies [J]. Accounting and economic research, 2017(04):30-46.

[4] Cai guilong, Liu jianhua, Ma xinxiao. Governance of non-state-owned shareholders and incentive of executive compensation in state-owned enterprises [J]. Management world, 2018(5):137-149.

[5] Ma lianfu, Wang lili, Zhang qi. Optimal selection of mixed ownership: logic of market [J]. China industrial economy, 2015(7):5-20.

[6] Hao yang, Gong liutang. Mixed state-owned and private equity participation and corporate performance improvement [J]. Economic research, 2017(03):124-137.

[7] Yang xingquan, Yin xingqiang. How does the mixed reform of state-owned enterprises affect the company's cash holdings? [J]. Management world, 2018, 34(11):99-113. 